\title{
PENGARUH TELUR REBUS DALAM PENYEMBUHAN LUKA PERENIUM PADA IBU NIFAS DI KLINIK PRATAMA ARRABIH TAHUN 2020
}

\author{
Eka Maya Saputri , Ega Febiola \\ STIKES HANG TUAH Pekanbaru
}

\begin{abstract}
One of the causes of the complication of the puerperium to the death of the puerperium is the occurrence of infection in the perineal wound due to a lack of adequate wound care, which can lead to secondary bleeding during the puerperium, and can lead to local and general infections. The impact of perienum suture wounds can cause infection and disruption of movement and activity of the mother. Acceleration of wound healing during the puerperium is expected, one of which is by consuming high protein, namely eggs. This study aims to determine the effect of giving boiled eggs on the healing of perineal wounds in postpartum mothers. Method This case study uses a descriptive observational method with a continuity of care approach given to the post-partum mother, Mrs. L at the Arrabih Pratama Clinic, Pekanbaru City from September 1-5 2020. Analyze data by comparing the data obtained with existing theories. Midwifery care for postpartum mothers by consuming boiled eggs for healing perineal wounds was carried out for 5 days. The final result is the effectiveness of consuming boiled egg whites on the perineal wound healing process. It is hoped that midwifery care providers who are practicing will always maintain existing midwifery services and continue to develop the latest knowledge.
\end{abstract}

Keywords: Maternity care, Perineum, Boiled Eggs

\section{INTISARI}

Salah satu penyebab terjadinya penyulit masa nifas sampai dengan pada kematian puerperium adalah terjadinya infeksi pada luka perineum karena kurangnya perawatan luka yang memadai sehingga dapat menimbulkan perdarahan sekunder kala nifas, dan dapat memicu timbulnya infeksi yang bersifat lokal maupun general. Dampak yang ditimbulkan dari luka jahitan perienum dapat menyebabkan infeksi serta terganggunya gerak dan aktivitas ibu. Percepatan penyembuhan luka dalam masa nifas sangat diharapkan, salah satunya dengan konsumsi tinggi protein yaitu berupa telur. Penelitian ini bertujuan untuk mengetahui pengaruh pemberian telur rebus terhadap penyembuhan luka perineum pada ibu nifas. Metode Studi kasus ini menggunakan metode deskriptif observasional dengan pendekaan continuity of care diberikan pada ibu nifas Ny. L di Klinik Pratama Arrabih, Kota Pekanbaru dari tanggal 1-5 September 2020. Analisa data dengan membandingkan antara data yang diperoleh dengan teori yang ada. Asuhan kebidanan pada ibu nifas dengan mengkonsumsi telur rebus untuk penyembuhan luka perineum ini dilakukan selama 5 hari. Hasil akhir terdapat efektifitas konsumsi putih telur rebus terhadap proses penyembuhan luka perineum. Diharapkan kepada penyedia tempat pelayanan asuhan kebidanan yang sedang menjalankan praktik untuk selalu mempertahaankan pelayanan kebidanan yang sudah ada dan terus mengembangkan ilmu-ilmu terbaru.

Kata Kunci $\quad$ : Asuhan kebidanan kehamilan, Perineum, Telur Rebus 
PENDAHULUAN

Masa nifas berasal dari bahasa latin yaitu dari kata "puer" yang artinya bayi dan "paraous" yang berarti melahirkan. Masa nifas dimulai setelah plasenta lahir dan berakhir ketika alat-alat kandungannya kembali seperti keadaan sebelum hamil, biasanya berlangsung selama 6 minggu atau 42 hari, namun secara keseluruhan berakhir ketika alatalat kandungannya kembali seperti keadaan sebelum hamil. Masa nifas berlangsung kira-kira $6 \quad$ minggu (Ambarwati dan Wulandari, 2010).

Data dari Kementerian Kesehatan Republik Indonesia (Kemenkes) tahun 2015 menunjukkan bahwa dari 100.000 kelahiran hidup di Indonesia, 305 di antaranya berakhir dengan kematian sang ibu (Profil Kesehatan Indonesia, 2015). Sementara AKI di Provinsi Riau jika dilihat data beberapa tahun sebelumnya dimana jumlah kematian ibu tahun 2014 sebanyak 153 kasus kematian ibu dan pada tahun 2015 sedikit menurun menjadi 145 kasus dan menurun kembali di tahun 2016 menjadi 130 kasus kematian ibu.

Salah satu permasalahan kematian ibu nifas adalah luka perineum, Faktor-faktor yang mengakibatkan luka perineum adalah kesalahan mengejan, gawat janin, kelainan letak dan bayi besar.
Asuhan yang dapat diberikan pada ibu nifas dengan pemberian telur rebus. Pada kajian ini telur rebus untuk penyembuhan luka jahitan perineum pada ibu post partem karena percepatan penyembuhan luka perineum dalam masa nifas sangat diharapkan untuk menghindari ibu nifas dari bahaya infeksi (RatnaDewi, 2019)

\section{METODE STUDI KASUS}

Studi kasus ini menggunakan metode deskriptif observasional dengan pendekaan continuity of care diberikan pada ibu nifas Ny. L di Klinik Pratama Arrabih, Kota Pekanbaru dari tanggal 1-5 September 2020. Analisa data dengan membandingkan antara data yang diperoleh dengan teori yang ada.

\section{HASIL STUDI KASUS}

1. Kunjungan Nifas Pertama di Klinik Pratama Arrabih (12 post partum) pada tanggal 1 September 2020

a. Pengkajian Data Subjektif

Ny.L berusia 31 tahun, post partum 12 jam yang lalu, ia merasa senang karna telah melahirkan bayi, Ibu mengatakan ia merasa lelah dan takut nyeri saat ingin $\mathrm{BAB}$

b. Pengkajian Data Objektif

Setelah melakukan pemeriksaan data objektif didapat hasil yaitu TD: 120/80 mmHg, N: $80 \times / i, P: 20 \times / i, S:$ 
$36,5^{\circ} \mathrm{C}$, TFU 3 jari dibawah pusat, kontrasksi uterus baik, perdarahan \pm 20 cc berwarna merah kehitaman (lochea rubra), luka perineum derajat 2, kondisi luka normal dan telah diberikan antiseptik setelah bersalin, tidak ada perdarahan, odema (-), tidak terdapat tanda infeksi post partum.

c. Assestment

$\mathrm{P}_{3} \mathrm{~A}_{0} \mathrm{H}_{3}, 12$ jam post partum, K/U ibu baik dengan keluhan merasah lelah dan takut nyeri saat ingin $\mathrm{BAB}$

d. Plan

Informasikan hasil pemeriksaan, keluhan yang di rasakan, tidak perlu takut $\mathrm{BAB}$, mengevaluasi luka perineum, perawatan luka, menjaga kebersihan, menjaga pola makan, memberikan telur rebus, ASI esklusif, tanda bahaya masa nifas, therapy obat vitA, kunjungan ulang.

e. Implementasi

1) Menginformasikan bahwa keadaan ibu baik, dan semua dalam keadaan normal.

2) Menjelaskan Ibu bahwa lelah yang ibu rasakan adalah wajar karena ibu mengeluarkan banyak tenaga saat melakukan proses persalinan. Ibu harus istirahat yang cukup

3) Menjelaskan pada ibu tidak perlu takut untuk BAB karna lukanya sudah dijahit oleh Bidan. Agar tidak sakit saat BAB, perbanyaklah konsumsi serat seperti buah dan sayuran sehingga tinja yang dikeluarkan menjadi tidak keras dan ibu tidak perlu mengejan

4) Mengevaluasi luka perineum dan pengeluaran pervaginam. Keadaan luka baik, pus (-), darah (-), tidak ada tanda-tanda infeksi, pendarahan \pm yaitu lochra rubra, semua keadaan ibu dalam batas normal.

5) Jelaskan pada ibu tentang perawatan lukanya bahwa selesai BAK atau BAB luka harus dikeringkan dan jaga kebersihan vagina dan anus

6) Beritahu ibu untuk menjaga kebersihan diri terutama kebersihan darag vaginanya, usahakan mengganti pembalut sesering mungkin seiap \pm 4 jam atau jika pembalut telah terasa penuh

7) Anjurkan ibu menjaga pola makan yang beraneka ragam mengadung karbohidrat, sayuran, dan buah serta mengkonsumsi protein

8) Untuk mempercepat proses penyembuhan luka ibu, peneliti menyarankan kepada ibu untuk mengkonsumsi telur rebus karena dapat mempercepat penyembuhan luka, yaitu dengan mengkonsumsi 
sebanyak 4 telur putih setiap harinya 2 butir dipagi hari dan 2 butir disore hari selama 5 hari.

9) Evaluasi peneluaran ASI (ada) dan menjelaskan pada ibu untuk sesering mngkin bayi mengisap putting susu ibu sehingga merangsang ASI keluar karena reflex aliran

10) Memberitahu ibu tanda-tanda bahaya masa nifas

11) Memberi ibu obat kapsul Vit A 2 butir (diminum 1 kali)

12) Melakukan kunjungan ulang

2. Kunjungan Nifas Kedua di Rumah Pasien (3 Hari Post partum Pertama) Tanggal 3 September 2020 pukul 8.30 WIB

a. Pengkajian Data Subjektif Ibu mengatakan ASI nya lancar, ibu sudah tidak takut untuk BAB dan ibu telah mengkonsumsi telur rebus setiap harinya, masih merasakan nyeri pada luka jahitan.

b. Pengkajian Data Objektif

Setelah melakukan pemeriksaan data objektif didapat hasil keadan umum ibu baik yaitu TD: 120/70 mmHg, N: $82 \times / \mathrm{i}$, P: $22 \times / \mathrm{i}, \mathrm{S}: 36,6^{\circ} \mathrm{C}, \mathrm{TFU}$ pertengahan pusat-simpisis, kontraksi uterus baik, perdarahan $\pm 20 \mathrm{cc}$ berwarnah putih kemerahan (lochea sanginolenta), luka perineum sudah mulai sedikit kering, pus (-), odema () , infeksi perineum (-).

c. Assestment $\mathrm{P}_{3} \mathrm{~A}_{0} \mathrm{H}_{3}, 3$ hari post partum, K/U ibu baik

d. Plan

Informasikan hasil pemeriksaan, menjelaskan keluhan yang dirasakan, memberika relur rebus kembali, evaluasi luka perineum, cara perawatan luka, menjaga kebersihan, asi esklusif, perawatn payudara pola istirahat, kunjungan ulang memberitahu kunjungan ulang

e. Implementasi

1) Memberitahu ibu hasil pemeriksaan saat ini yaitu keadaan umum ibu baik dan semua dalam keadaan normal. Tidak ada yang perlu ibu khawatirkan

2) Menjelaskan ibu bahwa nyeri yang ibu rasakan pada lukanya adalah normal dan disebabkan oleh proses penyembuhan luka yang sedang berlangsung dan lama kelamaan akan hilang

3) Memberikan kembali ibu telur rebus untuk proses penyembuhan luka perineum agar luka cepat kering dan mencegah terjadinya infeksi

4) Evaluasi luka perineum dan pengeluaran pervaginam. 
Keadaan luka baik, tidak ada tanda infeksi, lochea rubra

5) Menjelaskan, kembali pada ibu tentang perawatan luka

6) Ingatkan kembali untuk menjaga kebersihan diri

7) Evaluasi pengeluaran asi kembali

8) Menjelaskan kembali dan mengajurkan ibu untuk melakukam perawatan payudara

9) Anjurkan untuk menjaga pola istirahat

10) Kunjungan ulang

3. Kunjungan Nifas Ketiga di Rumah Pasien (5 hari Post Partum) tanggal 5 september 2020 pukul 08.30 WIB

a. Pengkajian Data Subjektif

Ibu mengatakan bayinya semakin kuat menyusui, Ibu mengatakan sudah tidak meraskan nyeri pada luka jahitan. dan tidak memiliki keluhan lainnya

b. Pengkajian Data Objektif

Setelah melakukan pemeriksaan objektif didapatkan hasil yaitu saat ini keadaan umum ibu baik TD: 120/70 mmHg, N: $78 \times / \mathrm{i}, \mathrm{P}: 20 \times / \mathrm{i}, \mathrm{S}: 36,3^{\circ} \mathrm{C}$, TFU pertengahan pusat-simpisis, kontrasksi uterus baik, perdarahan \pm 10 cc berwarnah putih kemerahan (lochea sanguinolenta), luka perineum tampak kering ,Infeksi perineum(-), ASI lancer c. Assestmen

$\mathrm{P}_{3} \mathrm{~A}_{0} \mathrm{H}_{3} \quad 5$ hari post partum, K/U ibu baik

d. Plan

Informasikan hasil pemeriksaan, menjelaskan kepada ibu tentang keluhan yang ibu rasakan, memberitahu luka sudah kering memberi ibu rebus putih telur, , memberitahu asi ekslusif, memberitahu ibu tentang KB, menganjurkan hidup sehat bagi, memberitahu ibu agar bayinya mendapatkan imunisasi

e. Implementasi

1) Hasil pemeriksaan saat ini yaitu keadaan umum ibu baik, semua dalam keadaan normal.

2) luka jahitan ibu sudah kering.

3) Menganjurkan ibu untuk tetap memberikan ASI ekslusif pada bayinya

4) Menjaga pola makan dengan gizi seimbang dan tinggi protein seperti telur rebus serta pola istirahat yang cukup

5) Menganjurkan ibu untuk merencanakan metode $\mathrm{KB}$ yang akan ia gunakan sebelum masa nifas berakhir.

6) Jelaskan dan mengingatkan pada ibu agar bayinya mendapatkan imuniasi yang lengkap. Imunisasi bayi selanjunya yaitu saat usia nya 
satu bukan (satu bulan BCG di lengan dan Poli yang ditetes dimulut

\section{PEMBAHASAN}

Dalam teori Megasari et al ( 2019 ), data subjektif didasarkan pada apa yang dirasakannya atau diyakininya oleh klien ketika klien tersebut mengungkapkan apa yang dirasakannya kepada bidan yang dinamakan dengan anamnesis. Data subjektif harus digali secara fokus untuk menghindari hal-hal yang tidak diperlukan atau yang bukan ranah bidan. Dalam pelaksanaan asuhan pada tanggal 01 September 2020 yang di lakukan diKlinik Pratama Arrabih, data subjektif yang di temukan Ny. L mengatakan merasa lelah dan takut ingin BAB. Berdasarkan data yang di peroleh tidak ada kesenjangan antara kasus dan teori Megasari et al (2019). Berdasarkan teori yang di kemukakan oleh Wahyuni (2018) perubahan-perubahan fisiologis pada masa nifas dan menyusui mulai dari adaptasinya perubahan fisik, yaitu meliputi; perubahan sistem tubuh pada masa postpartum dan adaptasi pemenuhan kebutuhan fisiologis postpartum. selaras dengan kasus yang di temukan pada Ny.L

Dalam penanganan pada studi kasus Asuhan Kebidanan pada ibu nifas dengan mengkonsumsi telur rebus untuk penyembuhan luka perineum ini penulis memberikan asuah kebidanan dengan menjelaskan penatalaksanaan umum untuk kondisi ibu dan mengajarkan ibu untuk mengkonsumsi jenis telur ayam ras yang sudah di rebus dan yang harus dimakan putihnya saja untuk percepatan penyembuhan luka perineum selama \pm 5 hari. . Hasil yang diharapkan setelah melakukan asuhan kebidanan pada ibu nifas dengan mengkonsumi telur rebus yaitu bisa mempercepat penyembuhan luka perineum kontrasksi uterus baik, perdarahan $\pm 10 \mathrm{cc}$ berwarnah merah kehitaman (lochea rubra), luka perineum, kondisi luka baik dan telah diberikan antiseptik setelah bersalin, pus (-), darah (), odema (-), infeksi perineum (-) sesuai dengan teori yang di kemukakan oleh Megasari et al (2019)

Untuk mempercepat penyembuhan luka pernium, ibu bisa mengkonsumsi makanan yang tinggi protein seperti telur rebus pada \pm 5 hari pertama. Kebutuhan gizi pada masa nifas terutama bila menyusui akan meningkat $25 \%$, karena berguna untuk proses kesembuhan karena sehabis melahirkan, dan untuk memproduksi air susu yang cukup untuk menyehatkan bayi

\section{KESIMPULAN}

Setelah melaksanakan asuhan kebidanan pada Ny.L denagn perawatan luka perineum mulai dari pengkajian data 
hingga evaluasi dan kemudian dilakukan perbandingan atara teori dengan kasus yang ada, maka penulis mengambil kesimpulan:

1. Telah dilakukan asuhan kebidanan pada ibu nifas Ny.L dengan luka perineum di Klinik Pratama Arrabih Pekanbaru pada tanggal 01 September 2020 pukul : 12.00 WIB dan dilanjutkan dengan kujungan ulang dirumah pasien sebanyak tiga kali pada tanggal 01-05 September 2020

2. Pada saat dilakukan asuhan kebidanan masa nifas pada Ny.L ditemukan luka perineum. Kemudian saat pemeriksaan objektif ditemukan kondisi luka dalam keadaan baik, pus (-), darah (-), odema (-), saat kunjungan terakhir yaitu pada hari ke 5 post partum luka bagian luar telah kering dan tidak ditemukan adanya tanda-tanda infeksi. Dalam upaya menurunkan angka resiko terjadinya infeksi penulis memberikan olahan ikan gabus untuk proses penyembuhan luka. Proses penyembuhan berlangsung hingga fase proliferasi sesuai dengan teori yang ada

3. Asuhan kebidanan pada Ny.L dengan luka perineum telah dilaksanakan sesuai dengan rencana asuhan dan tidak ditemukan kesenjangan dengan teori yang ada. Dalam pelaksanaannya penulis tidak menemukan hambatan karena pasien dapat bekerjasama dengan baik dan bersedia melaksanakan anjuran-anjuran yang disampaikan

\section{SARAN}

1. Bagi Klinik Pratama Arrabih

Diharapkan kepada penyedia tempat pelayanan asuhan kebidanan yang sedang menjalankan praktik untuk selalu mempertahaankan pelayanan kebidanan yang sudah ada dan terus mengembangkan ilmu-ilmu terbaru

2. Bagi Instusi Pendidikan Stikes HangTuah Pekanbaru

Sebagai referensi atau kajian mengenai efektifitas konsumsi putih telur rebus terhadap proses penyembuhan luka perineum pada ibu nifas.

3. Bagi Ibu Nifas

Sebagai bahan masukan untuk memperhatikan asupan nutrisi khususnya putih telur baik untuk proses penyembuhan luka perineum.

\section{DAFTAR PUSTAKA}

Ambarwati dan Wulandari. 2010. Asuhan Kebidanan Nifas. Yogyakarta :Nuha Medika

Bahiyatun. 2008. Buku Ajar Asuhan Kebidanan Nifas Normal. Jakarta: EGC

Dewi, Ratna. 2019. Pengaruh Pemberian Telur Ayam Broiler Terhadap Penyembuhan Luka Perineum Pada 
Ibu Nifas. Jurnal Action: Aceh Nutrition Journal Volume 4

Komala, Yeni. 2017. Pengaruh Konsumsi

Tinggi Protein Nabati Terhadap Kualitas Penyembuhan Luka

Perineum Pada Ibu Nifas di

Puskesmas Mlati II Kabupaten

Sleman. Fakultas Ilmu Kesehatan

Universitas Aisyiyah. Yogyakarta

Nurulhatam, Esti. 2016. Keefektifan

Penyembuhan Luka Perineum Dengan

Menggunaan Rebusan Daun Sirih

Merah dan Mengkonsumsi Telur

Rebus Pada Ibu Nifas Ny. K Umur 21

Tahun di BPM Sri Sudarsih

Kebumen. Sekolah Tinggi Ilmu

Kesehatan Muhammadiah Gombong

Pinggarsiwi, Clara, Suparyanto. 2015.

Asuhan Kebidanan Ibu Nifas Pada

Perawatan Luka Perineum di Ruang

Nifas Puskesmas Cukir Diwek

Jombang. Stikes Pemkab Jombang

Purnani, Weni Tri. 2019. Perbedaan

Efektifitas Pemberian Putih Telur dan

Ikan Gabus Terhadap Penyembuhan

Luka Perineaum Ibu Nifas, Fakultas

Ilmu Kesehatan Universitas Kediri

Rifani, Ulmi. 2017. Penerapan Konsumsi

Telur Ayam Rebus Untuk Percepatan

Penyembuhan Luka Perineum Pada

Ibu Nifas Di BPM Heni Winarti Desa

Jatijajar, Ayah, Kebumen. Sekilah

Tinggi Ilmu Kesehatan

Muhammadiah Gombong
Silvina, Dwi. 2015. Pengaruh Konsumsi Telur Rebus Terhadap Percepatan Penyembuhan Luka Perineum. Program Sarjana Kebidanan FKF Universitas Adiwangsa. Jambi Supiati, Siti Yulaikhah. 2015. Pengaruh Konsumsi Telur Rebus Terhadap Percepatan Penyembuhan Luka Perineum dan Peningkatan Kadar Hemoglobin Pada Ibu Nifas. Jurnal Terpadu Ilmu Kesehatan Volume 4 Trianingsih, Indah, Helmi Yeni dan Santi Fadilah. 2018. Pengaruh Telur Rebus Terhadap Percepatan Penyembuhan Luka Perineum Pada Ibu Nifas 1-7 Hri. Jurnal Ilmiah Keperawatan Sai Betik Volume 14

Wahyuningsih, Heni Puji. 2018. Bahan Ajar Kebidanan : Asuhan Kebidanan

Nifas dan Menyusui. Jakarta:

Kementerian Kesehatan Republik Indonesia

Wangti, Sri. 2018. Pengaruh Suhu dan Lama Penyimpanan Telur Terhadap Kualitas Telur Ayam Ras (Gallus L) di Instalasi Gizi RSUP Dr. Kariadi Semarang. Fakultas Ilmu Keperawatan dan Kesehatan Universitas Muhammadiah Semarang WHO. 2012.World Health Statistics. WHO World Health Organization (Vol.27).https://doi.org/10.2307/3348 165 